https://doi.org/10.18485/iipe_response2covid19.2021.ch12

\title{
NARRATIVES AND DISSENT IN TIMES OF COVID-19
}

\author{
Orietta E. Hernández Bermúdez ${ }^{1}$ \\ Mayra M. Bárzaga García \\ Sunamis Fabelo Concepción ${ }^{3}$
}

\begin{abstract}
The COVID-19 pandemic exacerbated a whole series of existing confrontations based on the development of a series of narratives in order to accentuate the contradictions. This work, based on a bibliographic review and discourse analysis, aims to present some examples in this regard, demonstrating how the politicization of the pandemic was used to fuel dissent. A qualitative perspective and a flexible design have been used, which takes advantage of different theoretical-methodological perspectives, as well as various methods that offer an interdisciplinary vision.
\end{abstract}

Keywords: pandemic, narratives, dissent, politicization, infodemic, cooperation

\section{INTRODUCTION}

The context of the COVID-19 pandemic, far from fostering a climate of cooperation and concerted international efforts to manage the complex situation, aggravated a strong process of confrontation that had been developing. On the one hand, a group of rising nations driven by China and Russia promote multilateralism, while on the other hand, the United States, under Donald Trump's administration, assumes a unilateral and protectionist tendency against international agreements

\footnotetext{
${ }^{1} \mathrm{MA}$, Associate Researcher and Assistant Professor at the Center for International Policy Research (CIPI), Cuba, orietta82@yahoo.es.

2 Professor and Researcher at the Center for International Policy Research (CIPI), Cuba, mayramarbg17@gmail.com.

${ }^{3} \mathrm{PhD}$, Researcher and Professor at the International Politics Research Center, where she is also a Project Manager and General Coordinator of the Research Team on Communication, Politics and International Relations, Cuba, sunamisfabeloc@yahoo.es.
} 
and the United Nations system - withdrawal from the Nuclear Agreement with Iran, from the Paris Agreement on Climate Change, against UNESCO, and threats against the World Health Organization (WHO).

The United States, once the driving force behind the existing international order, perceives a process of inter-systemic transition that is leading to a relative loss of its hegemony and generating a more consensual international leadership. In this sense, Washington is unwilling to cede quotas of power and tries to hinder the progress of multilateral trends and other actors that could rival its status. To this end, it implements isolationist policies and all kinds of policies that threaten the current international system, while China and other actors promote attitudes that even imply the creation of new international institutions. As a result, a structural systemic crisis is perceived to impact all sectors and regions.

Recent world events, such as climate change or the global crisis unleashed by the advance of the COVID-19 pandemic, show that the world needs new integrated dynamic processes. That is not a process of de-globalization but, on the contrary, of transforming the current international order and moving from neoliberal mechanisms, established in the 1980s, which are obsolete for the world's current circumstances, to new mechanisms of cooperation.

\section{COVID-19: COOPERATION VS POLITICIZATION}

In the context of COVID-19, international cooperation has been deployed in different ways. Both Africa and Asia, for example, tend towards openness, i.e., regionalism for the management of the health crisis. Asia and Africa are committed to all sub-regional integration mechanisms and have adopted common policies. Meanwhile, in Latin America and the Caribbean, each country, depending on its own political ideology, has applied national policies to manage the pandemic in a unilateral and disjointed manner, in most cases, ignoring WHO recommendations. The Latin American and the Caribbean region became the epicentre of the pandemic, even more so than the Sub-Saharan African sub-region, with much weaker health infrastructures.

In Asia, the first continent affected by the pandemic, the exchange and assertiveness of experiences and cooperation from the main organizations and integration and collaboration schemes have been essential for the management and control of the health crisis. In this regard, the constant interrelation with the WHO stands out. The effectiveness of the Asian experience, in general, is based on an attitude towards cooperation, a sign of its open regionalism and the coordination of its multilateral organizations, despite the broad framework of differences they share. The Confucian heritage that distinguishes Asians and particularly China, which 
puts the welfare of the community before the individual, implies elements of strength in the new situation, evidencing the cultural contrast instead of the misnamed authoritarian policies.

All these experiences at the political-institutional, economic and health crisis management levels should be important lessons for the Latin American region, an area affected by a single internal civil conflict, in the case of Colombia, and other security problems in Central America as a result of migration and drug trafficking.

The Latin American and Caribbean region continues to be the most unequal region in terms of income distribution among its population at the world level. This reality has been exacerbated in the context of the COVID-19 pandemic. Access to and quality of health systems, labour conditions, abandonment of rural areas, access to safe water, educational levels, overcrowding in poor neighbourhoods or access to technology all increase the level of exposure to infection and the limitations on protecting oneself in the region.

In this difficult scenario, each Latin American and Caribbean country, depending on its political party, has applied national policies to manage the health crisis in a unilateral and disjointed manner and, in most cases, disregarding the recommendations of the World Health Organization (WHO). Thus, the region became the epicentre of the pandemic, even surpassing the African continent.

It is important to point out that the Latin American and Caribbean region is marked by a shift to the right. In recent years, it has been characterized by the dismantling of the institutions and the reversal of the policies of "progressivism", as well as by the implementation of a more aggressive neoliberal agenda, aimed at reducing the role of the State and strengthening processes of privatization and denationalization of national strategic sectors. This change in the correlation of political forces has had an impact on the associative experiences that promoted a more autonomous vision of integration, leaving mechanisms such as UNASUR, ALBA, CELAC and MERCOSUR in a highly vulnerable situation, while at the same time having a negative impact on cooperation.

Thus, for example, in the case of the health crisis, the role of Cuban medical cooperation is fundamental since its role in the region has been prominent at other times. However, the new contexts have reversed this scenario. In Brazil, Bolivia and Ecuador, Cuban doctors who covered an important percentage of the assistance were removed from their posts, leaving millions of low-income people without access to these health services.

However, Cuba strengthened its relations with CARICOM member nations. Since the beginning of the COVID-19 pandemic, several Caribbean countries have requested an increased Cuban medical presence. As a result, several brigades went 
to Suriname, Jamaica, Dominica, Belize, St. Vincent and the Grenadines, St. Kitts and Nevis, Honduras, Anguilla and Martinique and others, where they have been progressively incorporated, not to mention their collaboration in other regions. It is important to take into account the policy articulation that was achieved for the effective management of the crisis, which had in Cuba, as well as in European countries, important actors who managed the Cuban collaboration in European overseas territories located in the Caribbean (Collective authorship, 2020).

\section{CUBAN MEDICAL COOPERATION IN THE CONTEXT OF COVID-19}

In the difficult context of the pandemic unleashed by COVID-19 and the hostility of the United States government, on March 18, 2020, the first out of the 22 medical brigades that would provide services against this disease left Cuba. Gradually, more than 1,466 Cuban health professionals, integrated into 23 "Henry Reeve" medical brigades, went to 22 nations in Europe, Latin America and the Caribbean, Africa and the Middle East to reinforce health systems in the fight against the pandemic, a number that continued to grow. After the departure of the last group of Cuban doctors (June 26) to an African country and two Caribbean territories, Cuba had a total of 38 brigades in 31 countries with a total of 3,440 health specialists to face the pandemic. It is noteworthy that more than 45 countries in the world have requested assistance from Cuban physicians. The largest number of such medical brigades is in Latin America and the Caribbean, followed by Africa, and, for the first time, a brigade has arrived in Europe.

The economic retribution of Cuban medical collaboration has been one of the most controversial and thorny issues in recent years. This particular issue has been highly politicized in order to delegitimize the Cuban political system, considering that it is one of its main pillars. However, economic retribution is not what distinguishes medical collaboration. At present, there are three modalities of cooperation that are also used in the face of the COVID-19 pandemic: 1) In the case of very poor nations, Cuba assumes the expenses; 2 ) the expenses are shared with the country receiving the collaboration; and 3) the island receives income. In this regard, a recent example of this is argued by Dr Carlos Pérez Díaz, head of the Cuban brigade in Lombardy, who informed the local press: "We have not discussed any type of payment. We are here to collaborate; the Italian government has assured us accommodation and food. Our action in this region is purely of solidarity"(Collective authorship, 2020).

In the context of the current pandemic, new threats fall on Cuba and the world in relation to the medical cooperation developed. On June 17, 2020, a group of Republican senators in the United States introduced a bill to punish countries that 
contract medical missions from Cuba, considering them accomplices in "human trafficking". The U.S. Secretary of State, Mike Pompeo, led the accusations. He described the deployment of Cuban doctors in countries from Venezuela to Brazil to Ecuador as "sinister interference in their affairs", and congratulated countries, such as Bolivia, that have expelled them. Pompeo was backed by other top U.S. officials and agencies, including Deputy Secretary of State Michael Kozak, who has also seized on recent claims about the doctors' working conditions.

At this difficult juncture, Cuba maintains its conviction and commitment to solidarity with the world, including the United States. This country prevented the entry of a shipment of aid from China through the company Alibaba and torpedoed the negotiation with other companies to acquire material necessary to face the crisis and, therefore, makes this type of negotiation wearisome for the Cuban side. Despite that, Havana provided its support to Washington in the current health crisis from the beginning, just as it has helped many other countries, including the passengers of the British cruise ship MS Braemer, which docked on Cuban shores despite having at least five confirmed coronavirus cases onboard and another 52 passengers showing symptoms. The ship, with more than 600 mainly British passengers, had requested assistance from both Cuba and the United States. After being anchored in the Caribbean for five days looking for a place to dock, it was able to reach Cuba. This fact was another of the many that have been manipulated to delegitimize Cuba's image in the world.

\section{NARRATIVES IN THE CONTEXT OF COVID-19}

The year 2020 has been marked by a series of trends in the field of political communication, which have been related in one way or another. On the one hand, populist narratives of a nationalist, xenophobic nature, have been exacerbated, and on the other, these have been part of the terrible world scenario marked by the COVID-19 pandemic. These narratives have been used to generate messages in line with these emerging political forces on the confrontation and management of the crisis, which has led to politicization of this complex scenario and polarization in its management.

One of the main narratives generated is the anti-Chinese one. It is associated with the appearance of the disease in Wuhan province. This triggered a context of uncertainty and social alarm. The anxiety caused by the call to confine people to their homes was added to the high levels of stress caused by the threat of contracting a virus, which was showing significant lethality rates. In this context, overexposure to information on the subject accelerated. This was accompanied by fake news, hoaxes, rumours, conspiracy theories, thus generating an environment 
of great disinformation (Colomina, 2020). The information-disinformation paradox was ratified as an instrument of power, through which it is possible to viralize fear and confusion and sow social panic.

In this line, the WHO together with the PAHO considered it pertinent to make a call from the issuance of a document warning about this phenomenon associated with the infodemic: Psychosocial and mental health considerations during the outbreak of COVID-194, dated March 12, 2020. Below are some excerpts from the document that point out certain issues that may be relevant to the issue at hand, as they undoubtedly have a direct influence on those trends that were considered from the early stages of the pandemic to be likely to begin to develop:

"This virus should not be associated with any ethnic group or nationality. Show empathy to all affected people, within a given country or from any country. Remember that people who are affected by COVID-19 have done nothing wrong, are blameless and deserve our support, compassion and kindness. (...)" "Do not refer to people who have the disease as "COVID-19 cases," the "victims," the "COVID-19 families," or the "sick." These are "people who have COVID-19", "people who are in treatment for COVID-19", "people who are recovering from COVID-19" and who, once they have overcome the disease, will move on with their lives, their work, their family and their loved ones. It is important to separate the person from having an identity defined by COVID-19, to reduce stigma."

"Minimize the time you spend watching, reading or listening to news that causes you anxiety or distress. Seek information only from reliable sources and primarily about practical measures that will help you make protective plans for you and your loved ones. Look for information updates once or twice a day, at specific times. The sudden and almost constant flow of news about an outbreak can make anyone feel concerned. Be informed about what is actually happening, do not listen to rumours and misinformation. Gather information at regular intervals, from the WHO website, the PAHO website, and from national and local health authority platforms, to help you distinguish fact from rumor. Knowing reliable information can help minimize fear."

Undoubtedly, the indications referred to speak of a warning against the phenomenon of stigmatization in the context of the pandemic: the fear of otherness and all that can be attributed to it in the context of a health emergency. The survival

\footnotetext{
${ }^{4}$ Psychosocial and mental health considerations during the COVID-19 outbreak, retrieved from https://www.paho.org/es/documentos/consideraciones-psicosociales-saludmental-durante-brote-covid-19.
} 
instinct in extreme situations, which can be maximized and manipulated by large media conglomerates, so prone to the spectacularization of everything that happens according to certain interests, also has clear intentionality. It may or may not be perceived by the common citizen, and therefore, it is a source of hoaxes, rumours and fake news, or ultimately generates confusion or distrust. The "Theory of Rumour" and the study of "Social Representations" are important theoretical references from psychology and sociology from which the study of this phenomenon can be approached.

Thus, in relation to the pandemic, among the main narratives exploited by the mass media, three fundamental ones can be highlighted, in which the common citizen is a coparticipant and from which he dialogues with the environment around him and explains the events that affect him: conspiracy theories (politic and economic), apocalyptic predictions (religion) and environmentalist theories (naturalist).

Among the debates that have been most controversial by the media, the one referring to the origin of the virus and a whole series of speculations about it stands out. Among others, the most widespread belong to the conspiracy theory and reproduce the confrontation between the three protagonists, China, Russia and the United States.

Thus, for example, one can cite the case of the United States where former President Donald Trump gave a political focus to the issue by identifying the pandemic as "China's virus". It can be said that the new context marked by the pandemic of the new coronavirus, unleashed in the Chinese province of Wuhan, and the growing Sino-US confrontation, have greatly nuanced the scenario of the "crusade against terrorism of Islamic origin" that has prevailed in international relations for almost 20 years. Discourses and narratives are beginning to turn against a new target: Chinese stigma and its potent influence on the new world order.

In the context of a health emergency, it is natural that a debate arises as to who is best equipped to deal with the pandemic. Amid the difficult health situation with the advance of COVID-19, few countries have had an effective response based on national health infrastructures, whether in terms of scientific-technological and productive capacity, the development of the biotechnology and pharmaceutical industry, financial resources, and highly qualified or trained personnel. In this regard, the positions of the Republic of Korea, China, Singapore, Japan, India, Thailand and Vietnam have stood out (González, 2020).

However, these debates are frequently simplified by distinguishing between the strategies pursued by so-called liberal democracies and those pursued by socalled authoritarian regimes, the latter being identified with Asian regimes that, allegedly, can impose much stricter measures on their populations due to their 
nature of permanent surveillance, centralism, and control capacity. According to the South Korean philosopher Byung-Chul Han, author of "The Tired Society", in Asia, especially in China, people are less reluctant and more obedient than in Europe, and they also trust the State more. In Korea and Japan, too, daily life is much more strictly organized than in Europe. Above all, to deal with the virus, Asians are betting heavily on digital surveillance. They believe that big data could hold an enormous potential for defending against the pandemic. It could be said that in Asia, epidemics are not only fought by virologists and epidemiologists, but above all by computer scientists and big data specialists. A paradigm shift from which the West still has much to learn. Thus, apologists for digital surveillance would claim that big data saves human lives. According to this author, this is because critical awareness of digital surveillance is practically non-existent in Asia, and there is hardly any talk of data protection anymore, even in liberal states such as Japan and Korea. Nobody gets angry about the frenzy of the authorities to collect data. ${ }^{5}$ So, there is a confrontation and a debate about policy models in relation to the disruptive capabilities of technology.

Another debate that has opened up is the role of the nation-state and its institutions in a contingency such as the one we are facing. The crisis reinforced its border and anti-immigrant discourse, as well as the call to reactivate the country's economy. This reading of the confinements was also associated with the curtailment of freedoms and manifested divergent positions in the management of the crisis between the so-called liberal democracies and the so-called authoritarian regimes. Thus, a whole series of narratives emerged that not only politicized the health crisis and its management, but also international cooperation initiatives such as the Health Silk Road, which is part of the Chinese Belt and Road Initiative, which has been highly questioned and labelled as "mask diplomacy" with which China has the

\footnotetext{
${ }^{5}$ There are 200 million surveillance cameras in China, many of them equipped with a very efficient facial recognition technique. They even capture moles on the face. The whole infrastructure for digital surveillance has now proved to be extremely effective in containing the epidemic, to the extent that it measures body temperature and, if the temperature is of concern, they receive a notification on their cell phones. Drones are used to monitor quarantines. Chinese cell phone and Internet providers share their customers' sensitive data with the security services and the Ministries of Health. Thousands of digital investigation teams have been formed in Wuhan to search for potentially infected people based on technical data alone. Based on macro data analysis alone, they find out who is potentially infected, who has to be further observed and eventually isolated in quarantine. More information in Byung-Chul Han. The viral emergency and the world of tomorrow. Wuhan Soup. Digital book. Available on the Internet. Publisher: ASPO (Preventive and Compulsory Social Isolation). March 2020.
} 
opportunity to set itself up as "the donor saviour" and continue advancing its mega project; as well as others coming from Russia or Cuba.

The context of COVID-19, coinciding with an election year in the US, far from being an obstacle for Donald Trump's campaign, allowed him to exploit this type of discourse and increase his popularity, skillfully managing the concerns of Americans, channelling feelings such as hatred and fear towards the "enemies of the United States". This phenomenon of demonizing socialism has also been manifested internally in that country. At the level of social representations, the metaphor of "socialism" or "communism" associated with the Democratic Party, first through the figure of Bernie Sanders and then through Joe Biden and Kamala Harris, has had special significance in the discourse and symbolic system of Americans.

The great polarization that characterizes this society became evident in the November 2020 elections, which were conditioned by a climate of tension and exacerbated violence, which has been stoked in the speeches during all these years, and has been revealed in both Republican and Democratic supporters.

In the case of the European Union (EU), it is important to point out that this crisis has manifested and strengthened the phenomenon of fragmentation within the $\mathrm{EU}$ in various aspects. The limitations on the part of the EU in coordinating measures whose responsibility lies primarily with the Member States (health policy or border control) became evident. Trends such as "my country first" were also reproduced, resulting in the limitation of exports of health materials between the Member States and closure of national borders. In addition, there was a lack of coordination at the European level of the measures taken by the Member States (Morillas, 2020).

The coronavirus crisis has served the European extreme right to relaunch its discourse against the Schengen area of free movement. The spread of the pandemic has been used to blame migrants and to deepen the stigma against otherness.

The emergency triggered what some specialists considered "social hysteria". This scenario, for these political forces, represents an opportunity to erode the discourse of traditional governments, promote distrust in institutions and relaunch their border policy agenda. Thus, quarantines, anxious populations, fears, and an economy going into recession have characterized the European scenario and constituted, therefore, a breeding ground for citizens to be attracted by the most authoritarian, xenophobic and racist messages, in favour of the defence of the Nation States and against the European integration mechanisms (Collective of authors, 2020).

In the case of Latin America and the Caribbean, in the face of access to very unequal quality of health care, the inability to manage the crisis of many of the 
leaders representing the extreme right, who have opted for a discourse of scepticism in the face of the serious situation, advocating the revitalization of the economy and the cessation of the quarantine, has become evident. The case of the self-proclaimed president of Bolivia Jeanine Añez stands out in her appearance, who, while announcing the quarantine expressed: "Dear Bolivians, I ask you to join us in a permanent prayer. This Sunday begins a total quarantine and I ask that we may fast in prayer, repentance and faith, so that it may be our greatest weapon in the fight against this disease. May God bless Bolivia". However, the proposal to receive Cuban medical help was rejected de facto by Añez (Hernández, 2020).

For his part, Jair Bolsonaro called the pandemic a "gripecita" and has continued to campaign against the quarantine measures decreed by some state governors, such as Joao Doria in Sao Paulo or Wilson Witzel in Rio de Janeiro. Bolsonaro's antiquarantine campaign, which prayed "Brazil cannot stop", led Judge Laura Bastos Carvalho of Rio de Janeiro to order the Brazilian government to "refrain" from promoting attitudes of rejection of the confinement measures (Ayuso, 2020). Such have been the bolsonarista disasters with the management of the pandemic as, for example, the oxygen crisis in Manaus that has led Venezuela to send oxygen and several parties to request an impeachment in Congress.

Another side of the coin is, for example, Nayib Bukele in El Salvador, an example of a great national division. Several human rights organizations have sounded the alarm about the warnings of authoritarianism shown by the young president, which were accentuated after the arrival of COVID-19. On the one hand, even his detractors admitted that Bukele acted quickly in the face of the pandemic threat with the closing of borders and strict confinement measures. On the other hand, however, there were complaints about the temporary restriction of constitutional guarantees such as the right to free mobility, as well as the detention and sending to containment centres of those who left their homes. At the same time, access to public information was severely restricted, and there were appointments and dismissals that were interpreted as moves to shield certain officials (Morales, 2020).

In general, in the international context, there has been no lack of questioning of certain measures that have been associated with greater social control of governments over individuals. A whole series of narratives have also been developed from religion, and science has been politicized, as efforts to find an effective vaccine candidate have been called a "race" or "competition". This has been compounded by multiple conspiracy theories. Thus, the politicization of the pandemic and its articulation in the narratives of certain conservative political forces, with xenophobic, radical, nativist projections, and in many cases labelled as neofascist, has intensified the already complex national and international scenarios. 


\section{COMMUNICATION SCENARIO}

The COVID-19 crisis has shown that the technological sphere has been fundamental for the world not to come to a complete standstill, just as it has been a fundamental space in which geopolitical competition has become evident. Therefore, the technological dispute will persist, but it could be considered, within the possible scenarios, new dimensions and certain nuances around it. The race for control of data and information is perpetuated as the most concrete expression of power. However, within the competition, there will coexist certain levels of cooperation that may be consolidated in the long term.

In addition and closely related to the above issue, the only form of consumption that almost certainly benefited during the crisis has been the Internet, a platform from which it was possible to partially give course to the "daily life" from promoting teleworking, international exchange of scientific communities to address strategies to manage the crisis itself, services to some extent, information, entertainment so important at a time when the call is to stay at home, even expressions of protest, denunciation in social networks, culture, education, among other experiences that will undoubtedly be enhanced and extended in the future.

So, the health crisis exponentially multiplied our dependence on devices and large technology companies. The quarantine has jeopardized the livelihoods of countless entertainment, culture, tourism, and fashion companies, while also bringing massive capital to technology platforms. According to specialists in the field, it is likely that the exponential accumulation of complex knowledge during these months in the fields of biotechnology, computer science, robotics, statistics, systems, or data engineering will complete in record time the technological revolution that has been developing (Carrión, 2020).

The huge injection of money and big data being provided to companies such as Google, Amazon, Facebook and Netflix is expected to give a major boost to the development of algorithmic intelligence. This scenario is especially envisaged for the health sector in terms of computer-based epidemic management, which would give enormous decision-making power to machines.

In this regard, it should be noted that during confinement, children and students, in general, are getting used to receiving information and knowledge through computers; the temperature or the geolocation of those affected by the virus is being monitored through cell phones; grandparents are even downloading applications to which they were reluctant; everyone has become familiar with Skype, Google Hangouts or FaceTime and millions of sports fans, faced with the worldwide suspension of championships, have begun to take to e-sports 
competitions (Carrión, 2020). So, the change in routines will mark the new pulses of technological development and its incorporation into everyday life.

At present, the most successful models of epidemic management are mainly Asian. They share the use of applications for monitoring citizens who have been in infected areas or who are suffering from the disease. In general, the world is preparing to implement new biocontrol strategies, which implies the possibility of governments gaining access to our coordinates and DNA or delegating part of their decisions to artificial intelligence.

However, never before, the various technological advances that have a direct impact on people's lives call for the need to redefine human dignity in their daily lives shared with technology, an issue that has remained an unresolved matter.

In this regard, one of the main challenges is technological change and its impact on production models and employment, for example. We are going through an enormous transformation of the labour market, which will undoubtedly deepen in the future. This change is due to the intervention of technology in the type of functions performed by humans in the professional environment, and this, in turn, is fueling a very marked increase in inequality. Today's technological development is in direct collision with the functions that humans currently perform in the labour market. This process has a direct impact on the rapid scarcity of workers. In addition, this scenario has also highlighted the complex problem of the digital gap, and the contradiction of a world that is increasingly connected and more unequal in terms of access: The disconnected or the other face of the geopolitics of technology.

Latin America and the Caribbean and Africa are clear examples of this. In this context, the Latin American and Caribbean region underscores its status as the most unequal in the world, and increased dependence on the use of digital technologies exacerbates these inequalities. There are also strong inequalities in the rate of connectivity, according to income segments. ${ }^{6}$

Although plans have been made to promote the use of digital devices in education systems, many educational institutions do not have the necessary digital

\footnotetext{
${ }^{6}$ Latin America faces challenges in ICT training for teachers. For example, in Brazil in 2018, only $20 \%$ of teachers participated in a continuing education course for the use of computers and the Internet for teaching. Regarding Internet use, 16\% reported using it once or more times a day; while $20 \%$ used it once a week, and $18 \%$ at least once a month (Internet Steering Committee in Brazil, 2019). (See more in ECLAC Special Report Latin America and the Caribbean in the face of the COVID-19 pandemic, retrieved from https://www.cepal.org/es/publicaciones/45337-america-latina-caribe-la-pandemiacovid-19-efectos-economicos-sociales.
} 
technology infrastructure. In addition, there are gaps in access to computers and the Internet at home, so distance teaching and learning processes are not guaranteed. There are disparities in access to digital devices and broadband Internet access between urban and rural populations, between genders, between populations that speak or do not speak the official language (Spanish or Portuguese), and between populations with and without disabilities.

The African case is even more worrisome on these issues considering the trends that have become more and more successful in dealing with preventive quarantine and controlling the health crisis. When we talk about the progress of Internet connectivity in Africa, there are many differences that need to be taken into account and not only inequality among countries, depending on the levels of development of each state and government policies regarding investment in the technology sector. There are also social and gender differences within each national reality, and very marked differences between rural and urban areas with respect to their possibilities of access and network coverage. On the other hand, Africa stands out for the scarcity of news in certain scenarios when compared to the volume of news flowing daily on the Internet about other regions and, above all, if it is taken into account the number of political events and structural problems accumulated in many African countries (Abreu, 2019).

\section{CONCLUSIONS}

In general, the COVID-19 pandemic has been part of the narratives that had already been developing in the discourses of the most conservative populist political forces. Protectionism has been one of the fundamental features. The defence of the people, understood as nationals, against the stigma of those who are different, foreigners or potential carriers of the virus. In the case of the widespread antiChinese narrative, this feature takes on greater significance because it is not only a potential carrier but also a possible generator.

These discourses have led to the development of isolationist tendencies when it comes to managing the health crisis. Added to this are the real limitations revealed in terms of international cooperation and management of this type of emergency. This has undoubtedly generated mistrust and uncertainty, which is conducive to narratives that seek greater political fragmentation, as opposed to the need to foster alliances and integrated dynamic processes. 


\section{REFERENCES}

Abreu, Varens, Luis, Edel. (2019). África en megabits. Los avances de la conexión a internet en África subsahariana en el siglo XXI y el mundo de las tecnologías de la información"( Africa in megabits. Internet connectivity advances in subSaharan Africa in the 21st century and the world of information technologies). Unpublished article.

Ayuso, Anna. (2020). Desigualdad en América Latina frente a la crisis del coronavirus [Inequality in Latin America in the face of the coronavirus crisis], retrieved from https://www.cidob.org/publicaciones/serie_de_publicacion/opinion/america_I atina/desigualdad_en_america_latina_frente_a_la_crisis_del_coronavirus. Accessed 2 June 2021.

Byung-Chul, Han. (2020). La emergencia viral y el mundo de mañana. Sopa de Wuhan [Viral emergency and the world of tomorrow. Wuhan Soup]. Digital book, retrieved from http://iips.usac.edu.gt/wp-content/uploads/2020/03/ Sopa-de-Wuhan-ASPO.pdf. Accessed 2 June 2021.

Carrión, Jorge. (2020). La biología está acelerando la digitalización del mundo [Biology is accelerating the digitization of the world], retrieved from https://www.google.com/amp/s/www.nytimes.com/es/2020/03/29/espanol/o pinion/coronavirus-revolucion-digital.amp.html. Accessed 2 June 2021.

ECLAC. Latin America and the Caribbean in the face of the COVID-19 pandemic, retrieved from https://www.cepal.org/es/publicaciones/45337-america-latinacaribe-la-pandemia-covid-19-efectos-economicos-sociales . Accessed 2 June 2021.

Authors' Collective (2020). Sin Fronteras. Mapa de la colaboración médica cubana [Without Borders. Map of Cuban medical collaboration]. Published in ALAINET, retrieved from https://www.alainet.org/es/articulo/208384. Accessed 15 June 2021.

Colomina, Carme. (2020). Coronavirus: infodemia y desinformación [Coronavirus: infodemic and misinformation], retrieved from https://www.cidob.org/es/ publicaciones/serie_de_publicacion/opinion/seguridad_y_politica_mundial/cor onavirus_infodemia_y_desinformacion. Accessed 15 June 2021.

González Sáenz, Ruvislei. (2020). El Covid-19 y su impacto económico en Asia pacífico en el 2020: Casos China y Vietnam [The Covid-19 and its economic impact in Asia Pacific in 2020: Cases China and Vietnam], retrieved from https://www.google.com/amp/saeeg.org/index.php/2020/04/14/el-covid-19su-posible-impacto-economico-en-asia-pacifico-en-el-2020-caso-china/amp/. Accessed 15 June 2021. 
Hernández Bermúdez, Orietta (2020). Bolivia en tiempos de la COVID 19". [Bolivia in times of Covid-19], retrieved from http://www.cubadebate.cu/especiales/ 2020/04/21/bolivia-en-tiempos-de-la-covid-19/\#.Xp84bchKjIW. Accessed 2 July 2021.

Morales Valido, Charly (2020). El Salvador despide al 2020 con más polarización y menos consensos [El Salvador says goodbye to 2020 with more polarization and less consensus], retrieved from https://www.prensa-latina.cu/index.php?o= rn\&id=417948\&SEO=el-salvador-despide-al-2020-con-mas-polarizacion-ymenos-consensos. Accessed 2 July 2021.

Morillas, Pol. (2020). Lecciones de una crisis global: coronavirus, orden internacional y el futuro de la UE [Lessons from a global crisis: coronavirus, international order and the future of the EU], CIDOB, notes internacionales, No. 231. 2020, retrieved from https://www.cidob.org/ca/publicacions/publicacio/notes internacionals/lecciones_de_una_crisis_global_coronavirus_orden_internacion al_y_el_futuro_de_la_ue. Accessed 1 July $202 \overline{1}$.

OPS. Consideraciones psicosociales y de salud mental durante el brote de COVID19 PAHO". [Psychosocial and mental health considerations during the COVID19 outbreak], retrieved from https://www.paho.org/es/documentos/ consideraciones-psicosociales-salud-mental-durante-brote-covid-19. Accessed 2 July 2021. 